\title{
Cultural Dimensions for User Experience: Cross-Country and Cross-Product Analysis of Users' Cultural Characteristics
}

\author{
Inseong Lee \\ Gi Woong Choi \\ Jinwoo Kim \\ $\mathrm{HCl}$ Lab, Yonsei University \\ Seoul 120-749, Korea \\ 822-2123-2528, Country code: 82 \\ nuno@yonsei.ac.kr \\ joshchoi@yonsei.ac.kr \\ jinwoo@yonsei.ac.kr
}

\author{
Solyung Kim \\ Kiho Lee \\ Daniel Kim \\ $\mathrm{HCl}$ Lab, Yonsei University \\ Seoul 120-749, Korea \\ 822-2123-2528, Country code: 82 \\ psyche14@yonsei.ac.kr \\ linus@yonsei.ac.kr \\ danielkim604@gmail.com
}

\author{
Myunghee Han \\ Seung Yong Park \\ Yongil An \\ UDS Group, Samsung Electronics \\ Seoul 100-130, Korea \\ 822-750-9261, Country code: 82 \\ sky.han@samsung.com \\ seungy.park@samsung.com \\ yongil.an@samsung.com
}

\begin{abstract}
The quality of user experience is intricately related to the users' cultural characteristics. However, not many studies have dealt with important cultural characteristics which are closely related to user experience. The main goals of this study are to identify important cultural dimensions that are closely related to the user experience of consumer electronic products and to measure them in different countries with different products. Contextual inquiries and online surveys were conducted in four different countries: the United States, Germany, Russia, and Korea. The study was participated by users of four different consumer electronic products: cellular phones, MP3 players, LCD-TVs, and refrigerators. The study identified ten cultural dimensions that were important to the user experience of consumer electronics. The cultural dimensions were also found to vary across the four different countries and four different products. This paper concludes with a discussion of the study's implications and its limitations.
\end{abstract}

\section{Categories and Subject Descriptors}

H.5.2 [User Interfaces] Theory and Methods

\section{General Terms}

Measurement

\section{Keywords}

Culture, Cultural dimensions, User experience

\section{INTRODUCTION}

In an increasingly global market, the effect of cultural differences on the use of computerized systems is a matter of great interest [5]. Cultural characteristics have been found to be important because a user's cultural profile shapes his/her

\author{
(C) The Author 2008
}

Published by the British Computer Society perceptions of a system's features [6]. For example, a given cultural profile will cause a user to pay attention to certain information and to ignore the rest [19]. A user's cultural profile may therefore be described as a cultural lens that filters out and organizes information regarding a system's features, which in turn affects how he/she sees that system [10]. Therefore, system features appropriate for one culture may not be suitable for others; and system design needs to be adapted for different cultures as well.

However, despite the obvious importance of cultural factors, only a few studies have been performed on cross-cultural issues in HCI $[1,2,4,8,15,24]$. This is partly because any such study must confront the difficulty of explicitly identifying and measuring the intangible concept of culture in the context of a particular system [25]. This difficulty has led most crosscultural HCI studies to assume that cultural propensities which are elicited in other contexts (such as those provided by Hofstede [11] and Hall [9]) will hold for the particular systems being studied (e.g., $[15 ; 25 ; 28]$ ). It is far from clear, however, that this inference is valid. Cultural characteristics detected within one system may not be transferable to another [24]. In other words, it is possible that cultural characteristics are structured incongruently in different context using different systems $[20 ; 22]$. For example, people may show different cultural characteristics when they are flying an airplane vs. riding a bicycle.

The main objective of this study was to investigate key cultural factors that substantially influence the user experience of computerized systems. In order to achieve the objective, we conducted two consecutive studies in four countries with users of four different consumer electronic products. The United States, Germany, Russia and Korea were selected because they represent a wide variety of cultural characteristics according to the prior studies in culture $[11,9]$. The cellular phone, MP3 player, LCD-TV, and refrigerator were selected because they are used in modern everyday life and highly susceptible to the cultural influence [2]. The devices are also becoming highly computerized in order for users to interact with them actively.

In the first study, we conducted a set of qualitative analyses to identify key cultural factors that were closely related to the user experience of consumer electronic products. Numerous cultural factors have been proposed by prior research, but it has not yet been identified which of those factors hold a high relevance to the user experience. In the second study, we conducted online 
surveys to measure the characteristics of the identified cultural factors. Different products, as well as different countries, were found to influence cultural characteristics within the user experience of consumer electronic products. Based on the results, practical implications of developing culture-centered systems are presented at the end of this paper.

\section{THEORETICAL BACKGROUND}

Culture has been defined in a number of different ways because of its multi-dimensional characteristics. For example, Kroeber and Parsons [14, p. 583] arrived at a cross-disciplinary definition of culture as "transmitted and created content and patterns of value, ideas, and other symbolic-meaningful systems as factors in the shaping of human behavior and the artifacts produced through behavior." For Hofstede [11, p. 25], culture is "the collective programming of the mind that distinguishes the members of one group or category of people from another." The cultural characteristics thus comprise a constellation of psychological traits, attributes, and characteristics [16].

Identifying cultural characteristics is difficult because we lack a robust measure that can identify the implicit levels of culture [25]. In an effort to address this issue, researchers have conceived of culture as a set of 'dimensions' that provide a framework for cross-cultural comparisons of user behavior [21]. Important work in defining cultural dimensions has been undertaken by Parsons and Shils [21], Kluckhohn and Strodtbeck [13], Hall [9], Hofstede [11], Trompenaars [26], and Schwartz [23].

Parsons and Shils [21] proposed five cultural dimensions to schematize the everyday behaviors of individuals: affectivity vs. affective neutrality, self-orientation vs. collective orientation, universalism vs. particularism, ascription vs. achievement, and specificity vs. diffuseness. In contrast to this bipolar approach, Kluckhohn and Strodtbeck [13] posited four basic traits that could each be considered in their own right: relation to nature (subjugation, harmony, mastery), relation to others (lineal, collateral, individualistic), time orientation (past, present, future), and personal activity (being, containing, doing). Hall [9], an anthropologist and cross-cultural communications researcher, developed a model of cultural dimensions based on years of observation and extensive interviewing throughout the world. He distinguished cultures along two dimensions: contextuality (high or low) and time perception (polychronic or monochronic). Hofstede [11] conducted a survey of IBM employees in 40 different countries and proposed a model that entailed four dimensions: uncertainty avoidance, individualism vs. collectivism, masculinity vs. femininity, and power distance. Hofstede and Bond [12] subsequently added the fifth dimension to their model, long-term vs. short-term orientation.

Trompenaars [26] developed a set of seven cultural dimensions based on a study involving 30 companies in 50 nations. His model takes Parsons and Shils's [21] five-dimension scheme as a foundation and incorporates some aspects of Hofstede's model. The seven dimensions of culture identified by Trompenaars are: universalism vs. particularism, individualism vs. collectivism, affective vs. affect-neutral communication style, specific vs. diffuse relationships, ascription vs. achievement, time orientation, and nature orientation. Finally, Schwartz [23] presented an alternative conceptual and operational approach for deriving cultural dimensions from work-related contexts. Drawing from his study of the content and structure of values held by individuals, Schwartz distinguished seven cultural value traits: conservatism, intellectual autonomy, affective autonomy, hierarchy, mastery, egalitarian commitment, and harmony. His model was based partly on Hofstede's [11] and Kluckhohn and Strodtbeck's [13] works and was tested using data collected between 1988 and 1992 from respondents in 48 cultural groups across 38 countries. Table 1 presents a comprehensive list of 36 cultural dimensions that have been mentioned in prior studies related to culture in general.

Table 1. A Comprehensive List of 36 Cultural Dimensions

\begin{tabular}{|c|c|c|c|}
\hline Dimensions & Reference & Dimensions & Reference \\
\hline Uncertainty Avoidance & {$[1]$} & Meaning of Life & {$[3]$} \\
\hline $\begin{array}{c}\text { Universalism vs. } \\
\text { Particularism }\end{array}$ & {$[21 ; 26]$} & $\begin{array}{c}\text { Nonverbal } \\
\text { Communication }\end{array}$ & {$[27]$} \\
\hline $\begin{array}{l}\text { Achievement vs. } \\
\text { Ascription }\end{array}$ & {$[21 ; 26]$} & $\begin{array}{c}\text { Political } \\
\text { Decentralization }\end{array}$ & [29] \\
\hline Activity Orientation & [3] & Power Distance & [11] \\
\hline $\begin{array}{c}\text { Affective (Emotional) vs. } \\
\text { Neutral Cultures }\end{array}$ & {$[21 ; 26]$} & Authority Conception & {$[3]$} \\
\hline $\begin{array}{c}\text { Human Nature } \\
\text { Orientation }\end{array}$ & [13] & Property & [3] \\
\hline Context & {$[9 ; 27]$} & Space & [9] \\
\hline Time Perception & {$[9 ; 26 ; 27]$} & Degree of Power & [29] \\
\hline Time Orientation & {$[3 ; 13]$} & Resources & [29] \\
\hline $\begin{array}{l}\text { Environment and } \\
\text { Technology }\end{array}$ & {$[27]$} & $\begin{array}{l}\text { Economic } \\
\text { Progress }\end{array}$ & [29] \\
\hline $\begin{array}{c}\text { International Trade and } \\
\text { Communication }\end{array}$ & [29] & $\begin{array}{l}\text { Technological } \\
\text { Development }\end{array}$ & [29] \\
\hline Face-Saving & [27] & Conservation & {$[23]$} \\
\hline $\begin{array}{l}\text { Masculinity vs. } \\
\text { Femininity }\end{array}$ & {$[11 ; 13]$} & $\begin{array}{l}\text { Affective } \\
\text { Autonomy }\end{array}$ & [23] \\
\hline $\begin{array}{l}\text { Individualism vs. } \\
\text { Collectivism }\end{array}$ & $\begin{array}{c}{[3 ; 11 ; 13 ;} \\
21 ; 26]\end{array}$ & $\begin{array}{l}\text { Intellectual } \\
\text { Autonomy }\end{array}$ & {$[23]$} \\
\hline $\begin{array}{c}\text { Instrumental vs. } \\
\text { Expressive Orientation }\end{array}$ & [21] & Mastery & {$[23]$} \\
\hline $\begin{array}{c}\text { Specific vs. } \\
\text { Diffuse Cultures }\end{array}$ & {$[21 ; 26]$} & Hierarchy & {$[23]$} \\
\hline Relationship to Nature & {$[13 ; 21]$} & Harmony & {$[23]$} \\
\hline $\begin{array}{c}\text { Long-Term vs. } \\
\text { Short-Term Orientation }\end{array}$ & [11] & $\begin{array}{l}\text { Egalitarian } \\
\text { Commitment }\end{array}$ & {$[23]$} \\
\hline
\end{tabular}

\section{THE OVERVIEW OF STUDY}

The 36 cultural dimensions presented in Table 1 may provide a comprehensive list of germane cultural dimensions. However, we do not know yet which of them are highly relevant to the use context of computerized device because cultural characteristics have been found to be substantially affected by the context of inquiry $[20 ; 22]$. In other words, people may exhibit different cultural characteristics when assessed in different contexts. Some of the dimensions from prior studies $[11 ; 12]$ are problematic in this regard because the dimensions are oriented to organizational settings and work-related activities, whereas computerized devices can also be used for personal purposes in non-employment settings [18].

Therefore, in order for HCI community to fully understand and utilize cultural dimensions, we need to find out which of the 36 dimensions are relevant to the use context of computerized devices and know how to measure them efficiently.

We conducted two consecutive studies. The first was a set of qualitative studies that were intended to identify key cultural dimensions relevant to the user experience of consumer electronics in four countries: the United States, Germany, Russia and Korea. The second was a quantitative study in the form of an online survey to actually measure cultural characteristics of user experience in the four countries.

The four countries were selected based on the findings of prior studies by Hofstede [11]. The study presented cultural 
characteristics of 65 countries in four dimensions (power distance, individualism/collectivism, masculinity/femininity, and uncertainty avoidance). We conducted K-means cluster analysis using Hofstede's dataset to identify cultural categories. ${ }^{1}$ The results indicated that the 65 countries can be classified into three big categories. The three countries (US, Germany, and Russia) were selected to represent each of the three categories, and Korea was used as the base country to prepare the entire research. By doing so, we were able to maximize the cultural variety of sample data while keeping the study cost/time within a reasonable range.

Four consumer electronic products were selected in order to represent various kinds of products. Cellular phones and MP3 players are mobile devices, whereas LCD-TVs and refrigerators are stationary devices. In addition, MP3 players and LCD-TVs are mostly hedonic products, whereas cellular phones and refrigerators are used mostly for utilitarian purposes. Finally, all the four products, nowadays, are heavily computerized and provide high level of interactivity, enabling us to investigate the cultural aspects of user experience in everyday life.

\section{THE FIRST STUDY}

The first study consists of three qualitative methods: online review analysis, expert interview, and contextual inquiry.

\subsection{First Study Method: Qualitative Analysis}

In order to identify important cultural dimensions efficiently, we initially performed online review analysis. Nowadays, many users actually post up reviews online [2]. Observing online reviews has its advantage in knowing the opinions of users without actually interviewing them. In this research, we collected user-written reviews from five popular websites for each product in each country (20 websites per country, 100 websites in total). More than 200 most recent reviews were collected and analyzed per site. We also specified that the review analysis should contain enough review posts for each major company and each major product model. Qualitative analysis was undertaken by using a case-ordered predictoroutcome matrix [17]; the matrix was modified to suit the online reviews. Any statements of the users that were related to the 36 cultural dimensions were identified. For example, a statement such as "Pink and red seem to be girly. I don't know about slim design, but I think there are definitely girly colors" indicated that masculinity/femininity was related to the cellular phone users. The review analysis was helpful in obtaining a glimpse of what the important cultural dimensions were before conducting the actual interviews. Twenty one dimensions were identified to be related to user experiences of the four products based on the online review analysis.

The first study also included an expert interview before the user interviews to find out what important cultural dimensions exist during the process of product development and what concepts the developer had in mind while designing the product. A team of two to three experts in marketing, product planning and UX were interviewed for each product in each country. They were paid participants. More detailed information about the number of experts interviewed in each country is presented in Table 2 . The expert interviews conducted in each country helped us in setting the basic approach to take for the contextual inquiry.

\footnotetext{
${ }^{1}$ The dataset we used for our cluster analysis was adopted from Hofstede's website (www.geert-hofstede.com) which presents the most updated version of cultural characteristics. Data for Korea, Russia, US, and Germany are being presented in the website.
}

The main results of the first study were produced from the contextual inquiry to find out which cultural dimensions are related to user experience with consumer electronic products. The contextual inquiry was divided into two parts: street interviews and home interviews. For the mobile devices (cell phone and MP3 player), both street interviews and home interviews were performed due to their mobile characteristics. For the home appliances (LCD-TV and refrigerator), only home interviews were performed.

More detailed information about the participants interviewed in each country is presented in Table 2. They were paid participants. Participants were told to use the products freely while the interviewers observed them. They were also asked to perform interactive tasks such as changing the desired temperature and activating anti-frost functions of refrigerator. After observations, interviews were performed. Interviews were based on questions asking about the overall experience with the product; and participants were asked to express their thoughts through questions regarding product usage. Finally, users' cultural dispositions were asked while they were using the products.

Table 2. Expert Interview \& Contextual Inquiry

\begin{tabular}{|c|c|c|c|c|}
\hline \multicolumn{5}{|c|}{ Expert Interview } \\
\hline & US & Germany & Russia & Korea \\
\hline & 6 experts & 4 experts & 9 experts & 8 experts \\
\hline \multicolumn{5}{|c|}{ Contextual Inquiry } \\
\hline & US & Germany & Russia & Korea \\
\hline $\mathbf{C P}$ & $\begin{array}{c}6 \text { users } \\
\text { (Gender: M 3, F } 3 / \\
\text { Average Age: } 24.2 \text { ) }\end{array}$ & $\begin{array}{c}10 \text { users } \\
\text { (Gender: M 4, F 6/ } \\
\text { Average Age: 25.4) }\end{array}$ & $\begin{array}{c}10 \text { users } \\
\text { (Gender: M 5, F 5/ } \\
\text { Average Age: 25.1) }\end{array}$ & $\begin{array}{c}9 \text { users } \\
\text { (Gender: M 7, F } 2 / \\
\text { Average Age: } 24.4 \text { ) }\end{array}$ \\
\hline MP3P & $\begin{array}{c}6 \text { users } \\
\text { (Gender: M 1, F } 5 / \\
\text { Average Age: } 24.5 \text { ) }\end{array}$ & $\begin{array}{c}10 \text { users } \\
\text { (Gender: M 4, F 6/ } \\
\text { Average Age: } 24.7 \text { ) }\end{array}$ & $\begin{array}{c}11 \text { users } \\
\text { (Gender: M 4, F 7/ } \\
\text { Average Age: 25.5) }\end{array}$ & $\begin{array}{c}10 \text { users } \\
\text { (Gender: M 7, F 3/ } \\
\text { Average Age: 22.9) }\end{array}$ \\
\hline TV & $\begin{array}{l}5 \text { households } \\
\text { (Average \# of } \\
\text { Household } \\
\text { Members: } 2.6 \text { ) }\end{array}$ & $\begin{array}{l}5 \text { households } \\
\text { (Average \# of } \\
\text { Household } \\
\text { Members: } 3.8 \text { ) }\end{array}$ & $\begin{array}{l}5 \text { households } \\
\text { (Average \# of } \\
\text { Household } \\
\text { Members: } 2.8 \text { ) }\end{array}$ & $\begin{array}{l}5 \text { households } \\
\text { (Average \# of } \\
\text { Household } \\
\text { Members: } 3.4 \text { ) }\end{array}$ \\
\hline Fridge & $\begin{array}{l}5 \text { households } \\
\text { (Average \# of } \\
\text { Household } \\
\text { Members: } 4.0 \text { ) }\end{array}$ & $\begin{array}{l}5 \text { households } \\
\text { (Average \# of } \\
\text { Household } \\
\text { Members: } 4.2 \text { ) }\end{array}$ & $\begin{array}{l}6 \text { households } \\
\text { (Average \# of } \\
\text { Household } \\
\text { Members: } 3.0 \text { ) }\end{array}$ & $\begin{array}{l}5 \text { households } \\
\text { (Average \# of } \\
\text { Household } \\
\text { Members: 4.2) }\end{array}$ \\
\hline
\end{tabular}

Transcribed interview data was obtained and was analyzed with the grounded theory, which allows researchers relying on qualitative empirical evidence to develop theoretical formulations that depict and explain specific phenomena [7]. Three steps of the grounded theory approach were conducted, first breaking down and conceptualizing the raw data, then categorizing concepts and finally analyzing relations between categories. The interview scripts were broken down by theme, that is, according to the cultural dimensions referred to or implied. Ten cultural dimensions have been identified to be relevant to the user experience of the four products from the grounded theory analysis of interview scripts. Many interviewees agreed that they experienced similar cultural dispositions while they were using one of the four products. Sample interview scripts of our participant are to be presented in the result section.

Finally, we developed survey questions for the ten dimensions based on prior research and contextual inquiry results. The survey questions that were used by prior research regarding the ten dimensions were adopted first. However, they were not related to the context of using the four products. Therefore, we added those expressions made by our interviewee on top of the existing questions. For example, one of the questions that was 
used for measuring individualism in existing literature, "the opinions of my friends do not affect my decisions," was paraphrased to be "the opinions of other people around me do not affect the usage of my cellular phone" in our study. Therefore, our survey questions are based on question items in prior research as well as our contextual interview data. Developed questions were reviewed through two focus group interview sessions with three participants each. Wordings and fitness between questions and cultural dimensions were checked through this process. Then pilot survey with 52 participants was performed as well. Survey participants commented on the questions after the survey. Through these processes, questions were modified to appropriately measure cultural dimensions.

\section{Table 3. Ten Critical Cultural Dimensions and Corresponding Questions}

\begin{tabular}{|c|c|}
\hline $\mathrm{UA}$ & $\begin{array}{l}\text { - While I use the cell phone, I prefer using it the same way as always than } \\
\text { making changes } \\
\text { - While I use the cell phone, if I face situation where I don't know how to } \\
\text { use it, I rely on someone who knows well about the cell phone } \\
\text { - While I use the cell phone, I tend to avoid using new functions that I've } \\
\text { never used before }\end{array}$ \\
\hline IC & $\begin{array}{l}\text { - I think my individual benefits which I gain from my cell phone is more } \\
\text { important than group benefits which people around me gain } \\
\text { - The opinions of other people around me do not affect the usage of my cell } \\
\text { phone } \\
\text { - While I use the cell phone, I often use it in my own way without relying } \\
\text { too much on the advice or opinions of people around me }\end{array}$ \\
\hline $\mathrm{MF}$ & $\begin{array}{l}\text { - I think men prefer to have a cell phone with better specifications and } \\
\text { functions than women do } \\
\text { - I think men can do better in dealing with functions of the cell phone than } \\
\text { women can } \\
\text { - I think men prefer the cell phone with a professional functions than } \\
\text { women do }\end{array}$ \\
\hline $\mathrm{CT}$ & $\begin{array}{l}\text { - While I use the cell phone, regardless of how I operate it, the result has to } \\
\text { be explained in a precise way } \\
\text { - I think a manual of the cell phone has to explain all the specifications and } \\
\text { functions as detailedly as possible } \\
\text { - I insist that all the specifications and functions of the cell phone should be } \\
\text { documented as a manual }\end{array}$ \\
\hline $\mathrm{TP}$ & $\begin{array}{l}\text { - I like to use several functions of the cell phone at the same time } \\
\text { - I am comfortable doing multiple activities simultaneously while using the } \\
\text { cell phone } \\
\text {-I like to do several activities at the same time while I am using the cell } \\
\text { phone }\end{array}$ \\
\hline TO & $\begin{array}{l}\text { - When I change my cell phone, I tend to change to cell phones that are } \\
\text { similar with my old cell phone } \\
\text { - It is likely that I compare and evaluate my current cell phone on the basis } \\
\text { of the one that I used in the past } \\
\text { - I prefer the cell phone which is similar to my former cell phone than the } \\
\text { cell phone with innovative functions or features }\end{array}$ \\
\hline $\mathrm{PD}$ & $\begin{array}{l}\text { - If I use a good cell phone, I think I can uplift my social status } \\
\text { - If I use a cell phone which is the same or better than someone who is in } \\
\text { higher position than I am, I feel as if my social status has improved } \\
\text { - I don't want to use the cell phone that is the same or worse than which my } \\
\text { subordinates have }\end{array}$ \\
\hline $\mathrm{AA}$ & $\begin{array}{l}\text { - For me, specifications and functions of the cell phone are more important } \\
\text { than the reputation of the company which created the cell phone } \\
\text { - When I evaluate the cell phone, I consider the functions and features more } \\
\text { importantly than the manufacturer of the product } \\
\text { - When I evaluate the function or features of my cell phone, I do not depend } \\
\text { on the manufacturer's reputation }\end{array}$ \\
\hline AN & $\begin{array}{l}\text { - While I use the cell phone, I consider emotional elements to be more } \\
\text { important than rational elements in the cell phone } \\
\text { - My cell phone is an emotional being for me rather than a rational being } \\
\text { - While I use the cell phone, I like feedbacks that make me emotional than } \\
\text { feedbacks that make me rational }\end{array}$ \\
\hline $\mathrm{CO}$ & $\begin{array}{l}\text { - In order to maximize the performance of the cell phone, I have to take the } \\
\text { full control of it } \\
\text { - All the functions of my cell phone must be under my control. } \\
\text { - All the outcomes of my cell phone operations should be under my } \\
\text { expectations }\end{array}$ \\
\hline
\end{tabular}

The derived cultural dimensions and corresponding survey questions for cellular phones are presented in Table 3. The questionnaires for the other three products were exactly the same as that for cellular phones except the product name. This was done for us to be able to compare cultural dimensions among the four products.

\subsection{First Study Results: Ten Cultural Dimensions}

Brief explanations of the ten cultural dimensions along with the data from the first study are presented below.

\subsubsection{Uncertainty Avoidance (UA)}

Uncertainty avoidance is the extent to which members of a culture feel threatened by uncertain or unknown situations [11]. Users with high uncertainty-avoidance level in our study worried that bad things might happen when they faced unfamiliar product features. For example, our participant stated, "I get worried when I use the new product." To avoid uncertainty, they relied on the opinions of others, including experts, and sought out for familiar situations in which events would be predictable. They also tended to avoid using new functions which they had never used before. On the other hand, users with low uncertainty avoidance level in our study were not anxious about being in unfamiliar situations; and they enjoyed exploring new functions.

\subsubsection{Individualism vs. Collectivism (IC)}

Individualism is a primary orientation to the self, whereas collectivism is a primary orientation to common goals and objectives $[13,26]$. Individualistic users in our study tended to care about their own interests and not to share them with others. They took pride in being unique and in expressing their personalities or identities. For example, a participant said, "I don't like to be the same as others." In contrast, collectivistic users felt good about knowing others' interests. They took pleasure in sharing their interests with others thereby maintaining and strengthening their social relationships.

\subsubsection{Masculinity vs. Femininity (MF)}

"Masculinity stands for a society in which social gender roles are clearly distinct, whereas femininity stands for a society in which social gender roles overlap [11, p.297]." For example, feminine-culture people believe that both men and women are supposed to be modest and tender alike, whereas masculineculture people believe that only women are so while men are supposed to be assertive and tough. Masculine users in our study believed that men could handle electronic devices better than women did. For example, one interviewee mentioned, "I think certain products are targeted for men, and certain products are targeted for women". Feminine users in our study believed that male and female users wanted the same specification and functions without any gender preferences.

\subsubsection{Contextuality (CT)}

Contextuality is the degree to which information conveyed in a communication or message is typically transmitted as a part of the context $[1,9]$. Users with high contextuality level in our study were pleased when information was expressed in a variety of ways. They enjoyed discovering the meaning of implicit expressions and had little difficulty in understanding information conveyed through visual distinctions. On the other hand, users with low contextuality level preferred direct and explicit communication and felt annoyed by showy expressions of extraneous information. For example, one participant said, 
"At first, I did not know it was the icon of a flash. Gee, I would prefer text over these kinds of pictograms."

\subsubsection{Time Perception (TP)}

Time perception is a fundamental aspect regarding two distinct notions of time [9, 26]: monochronic (M-Time) and polychronic (P-Time). A monochronic culture is task-oriented, emphasizes promptness and sticks to the original plans; whereas a polychronic culture tends to change plans and emphasizes relationships rather than tasks. Monochronic users in our study liked to focus on and perform one task at a time, proceeding in a sequential or linear manner. In contrast, polychronic users preferred to act in a parallel mode, doing many things at once and proceeding in a simultaneous or concurrent manner. For example, one participant said, "I listen to the music with my mobile phone as I send a text message to other person. Multi-tasking is not a problem for me."

\subsubsection{Time Orientation (TO)}

Time orientation refers to the importance of the value of the past and the present [12]. Time orientation is divided into shortterm and long-term orientation by how much users are influenced by the prior experience of electronic products usage. Long-term orientation pertains to focus on the values and benefits to be garnered in the future. Users of short-term orientation in our study were found to prefer products similar to the prior usage and tended to compare and evaluate new products with products which they used in the past. For example, a participant stated, "I tend to prefer my device similar to the ones in the past." On the other hand, prior experience did not seem to influence selection and evaluation of new products for the users of long-term time orientation.

\subsubsection{Power Distance (PD)}

Power distance refers to the extent to which the less powerful members of organizations or institutions accept and expect that power is distributed equally [11]. Users with high power distance in our study used products according to social status and felt like they could upgrade their social status by using better electronic products. For example, a participant said, "There is one upper classman who has a really good camera. I bought the camera which is the same level as his. Then I feel I am at the same level as he is." On the other hand, users with low power distance believed that there was no seeming correlation between social status and the type of electronic products they used.

\subsubsection{Ascription vs. Achievement (AA)}

Achievement refers to the way a culture accords the status based on how well performance is achieved while accordance deals with the way a culture accords the status based on who or what the person is $[21,26]$. The two different cultural tendencies were found to influence users' perception on basic functions and importance of specifications and brand when selecting electronic devices. Achievement-oriented users in our study tended to evaluate, select, and use products based on the functions and features of devices. For example, a participant said, "at first, I consider the functions most when I buy something." On the other hand, ascription-oriented users tended to focus more on the prestige and image of brand when buying and using consumer electronic products.

\subsubsection{Affective vs. Neutral (AN)}

Users of the affective culture communicate their emotions through language and expressions directly while users of the neutral culture have the tendency of being careful about expressing emotion and hiding them $[21,26]$. Our study results indicated that this cultural dimension is shown by whether users perceive an electronic product as an entity with emotions or as mere devices. Users of the affective culture believed that an electronic product was an entity with emotions and therefore should be treated affectively and that product feedback should also be affective. On the other hand, no emotions were involved with electronic products for those of neutral culture. For example, a participant said, "I evaluate the product with usage time and level of utility without considering emotions at all."

\subsubsection{Controllability (CO)}

Controllability refers to the degree of eagerness to dominate the surrounding environment $[13,23]$. Thus, when a problem arises, users with high controllability level tended to change the environment rather than themselves, whereas people under culture with low controllability tended to change themselves rather than the surrounding situation. Our study results indicate that users of electronic devices could be classified into low vs. high controllability groups according to their desire to control their devices. High controllability users in our study longed to know all the information about the product they were using and believed that he/she should take the full control of the devices in order to maximize device performance. For example, a participant said, "I like to set every option as I want so that I can control over my device."

\section{THE SECOND STUDY}

Based on the key cultural dimensions and the corresponding questions that were identified through the first study, online surveys were conducted in four countries in order to investigate how the cultural dimensions were different across different countries and different products.

\subsection{Second Study Method: Online Survey}

The questionnaire was administered through large-scale online surveys conducted in the U.S., Germany, Russia, and Korea around the same time. The survey questionnaire consisted of 30 questions; there were three questions for each of the ten cultural dimensions as shown in Table 3. They were asking cultural characteristics of people while they were using the four products on 7-point Likert scale. Respondents were solicited by local research agencies in each country. The meaning of each question was verified by the local research agencies. Stratified sampling method was used in order to balance age, sex and product model. At least 200 people participated for each product in each country. A total of 930 people participated in the U.S., 907 in Germany, 862 in Russia, and 1000 in Korea. A total of 910 people answered the cellular phone questionnaire, 945 people for the MP3 player, 921 for the LCD-TV and 923 for the refrigerator. Demographic profiles for the respondents in the four countries are shown in Table 4 . The average age of the respondents was early thirties and their gender was balanced.

Table 4. Demographic Information of Survey Respondents

\begin{tabular}{|c|c|c|c|c|c|}
\hline \multicolumn{2}{|c|}{ Country } & US & Germany & Russia & Korea \\
\hline \multicolumn{2}{|c|}{ Average Age } & 32.2 & 30.0 & 30.7 & 31.0 \\
\hline \multirow{2}{*}{ Gender } & Male & $46.7 \%$ & $47.9 \%$ & $50.7 \%$ & $50.5 \%$ \\
\cline { 2 - 6 } & Female & $53.3 \%$ & $52.1 \%$ & $49.3 \%$ & $49.5 \%$ \\
\hline
\end{tabular}

Exploratory factor analysis with the data from the entire sample $(n=3,699)$ was conducted to test the validity and reliability of the measurements. The 30 items were subjected to exploratory factor analysis with the Varimax rotation method. The results are summarized in Table 5. All 30 questions converged into their corresponding factors. For example, the three questions for power distance (PD2, PD1, and PD3) converged into a single factor across four countries. The cumulative variances 
explained were high, $74.06 \%$, and the eigenvalues of all the ten dimensions exceeded 1.0. The reliability of the measurements was tested by using the Cronbach's alpha coefficient. The coefficients of all dimensions exceeded the conventional threshold of 0.70 except for the power distance, affective/neutral, and controllability dimensions. Since the power distance, affective/neutral, and controllability dimensions almost reached the threshold value both in terms of the Cronbach's alpha coefficient and eigenvalues, we proceeded with the ten dimensions towards the analysis of cultural characteristics across different countries and products.

Table 5. Results for the Test of

\section{Measurement Reliability and Validity}

\begin{tabular}{|c|c|c|c|c|c|c|c|c|c|c|}
\hline & PD & AN & TP & MF & CT & $\mathrm{CO}$ & $\mathbf{A A}$ & UA & IC & TO \\
\hline PD2 & 0.90 & 0.22 & 0.06 & 0.13 & 0.03 & 0.04 & 0.02 & 0.08 & \begin{tabular}{|c|}
-0.01 \\
\end{tabular} & 0.09 \\
\hline PD1 & 0.88 & 0.23 & 0.05 & 0.13 & 0.04 & 0.08 & -0.00 & 0.06 & -0.01 & 0.08 \\
\hline PD3 & 0.86 & 0.20 & 0.05 & 0.14 & -0.00 & 0.03 & 0.03 & 0.10 & 0.02 & 0.07 \\
\hline AN2 & 0.24 & 0.87 & 0.05 & 0.10 & 0.03 & 0.05 & 0.08 & 0.06 & 0.02 & 0.06 \\
\hline AN3 & 0.23 & 0.85 & 0.09 & 0.07 & 0.06 & 0.11 & 0.08 & 0.05 & 0.03 & 0.07 \\
\hline AN1 & 0.18 & 0.81 & 0.03 & 0.10 & -0.03 & 0.01 & 0.13 & 0.14 & 0.06 & 0.09 \\
\hline TP2 & 0.02 & 0.02 & 0.91 & 0.02 & 0.05 & 0.16 & 0.08 & -0.04 & 0.08 & 0.03 \\
\hline TP3 & 0.03 & 0.06 & 0.90 & 0.03 & 0.01 & 0.12 & 0.06 & -0.00 & 0.08 & 0.05 \\
\hline TP1 & 0.11 & 0.09 & 0.73 & 0.08 & 0.28 & 0.17 & 0.08 & -0.10 & 0.03 & -0.05 \\
\hline MF3 & 0.09 & 0.06 & 0.05 & $\mathbf{0 . 8 8}$ & 0.13 & 0.05 & 0.02 & 0.02 & 0.05 & 0.06 \\
\hline MF1 & 0.07 & 0.07 & 0.07 & 0.85 & 0.05 & 0.07 & 0.04 & 0.07 & 0.11 & 0.03 \\
\hline MF2 & 0.21 & 0.13 & -0.01 & $\mathbf{0 . 8 0}$ & 0.10 & 0.04 & 0.04 & 0.06 & -0.01 & 0.07 \\
\hline CT2 & -0.05 & -0.01 & 0.09 & 0.06 & 0.88 & 0.14 & 0.05 & 0.07 & 0.03 & 0.03 \\
\hline CT3 & \begin{tabular}{|l|}
-0.04 \\
\end{tabular} & -0.04 & 0.12 & 0.06 & 0.86 & 0.18 & 0.02 & 0.04 & 0.03 & 0.04 \\
\hline CT1 & 0.19 & \begin{tabular}{|l|}
0.13 \\
\end{tabular} & 0.05 & 0.19 & 0.71 & 0.14 & 0.04 & 0.14 & -0.02 & 0.06 \\
\hline $\mathrm{CO} 3$ & 0.07 & 0.06 & 0.15 & 0.05 & 0.09 & 0.86 & 0.09 & -0.00 & 0.12 & 0.02 \\
\hline & 0.06 & 0.13 & 0.14 & 0.09 & 0.13 & 0.80 & 0.10 & -0.02 & 0.05 & 0.07 \\
\hline $\mathrm{CO} 3$ & 0.01 & -0.02 & 0.15 & 0.03 & 0.28 & 0.76 & 0.09 & -0.03 & 0.07 & -0.03 \\
\hline AA2 & 0.03 & \begin{tabular}{|l|}
0.01 \\
\end{tabular} & 0.13 & -0.00 & 0.10 & 0.12 & 0.87 & 0.04 & 0.08 & 0.03 \\
\hline AA1 & 0.10 & 0.05 & 0.08 & \begin{tabular}{|l|}
0.03 \\
\end{tabular} & 0.13 & 0.12 & 0.85 & 0.01 & 0.07 & 0.05 \\
\hline AA3 & -0.09 & 0.21 & 0.01 & 0.06 & -0.11 & 0.03 & 0.67 & 0.07 & 0.13 & 0.06 \\
\hline UA2 & 0.06 & 0.10 & 0.04 & 0.06 & 0.06 & 0.01 & 0.03 & 0.80 & -0.08 & 0.06 \\
\hline UA1 & 0.02 & -0.02 & -0.03 & -0.02 & 0.13 & 0.03 & 0.04 & 0.73 & 0.12 & 0.08 \\
\hline UA3 & 0.19 & 0.19 & -0.19 & 0.16 & 0.01 & -0.14 & 0.05 & 0.67 & 0.03 & 0.25 \\
\hline IC3 & -0.01 & 0.02 & 0.11 & 0.05 & -0.00 & 0.07 & 0.10 & -0.03 & 0.84 & 0.03 \\
\hline IC2 & \begin{tabular}{|l|}
-0.05 \\
\end{tabular} & -0.08 & 0.06 & 0.00 & 0.02 & 0.04 & 0.06 & 0.05 & 0.83 & -0.00 \\
\hline IC1 & 0.09 & 0.22 & 0.00 & 0.12 & 0.03 & 0.14 & 0.12 & 0.05 & $\mathbf{0 . 5 8}$ & 0.17 \\
\hline TO1 & 0.09 & 0.13 & -0.00 & 0.08 & -0.04 & -0.04 & 0.03 & 0.22 & 0.09 & $\begin{array}{l}0.81 \\
\end{array}$ \\
\hline $\mathrm{TO} 2$ & 0.02 & -0.04 & 0.14 & 0.04 & 0.23 & 0.20 & 0.06 & -0.05 & 0.02 & 0.73 \\
\hline TO3 & 0.18 & 0.20 & -0.13 & 0.06 & -0.07 & -0.13 & 0.09 & 0.36 & 0.09 & 0.65 \\
\hline Cronbach's $\alpha$ & \begin{tabular}{|l|}
0.66 \\
\end{tabular} & 0.67 & 0.84 & 0.81 & 0.86 & 0.68 & 0.92 & 0.76 & 0.89 & 0.82 \\
\hline Cumulative & \begin{tabular}{|l|}
9.01 \\
\end{tabular} & 17.59 & 25.57 & 33.39 & 41.19 & 48.71 & 55.57 & 61.90 & 68.11 & 74.06 \\
\hline Eigenvalues & 2.70 & 2.57 & 2.39 & 2.35 & 2.34 & 2.26 & 2.06 & 1.90 & 1.87 & 1.78 \\
\hline
\end{tabular}

\subsection{Second Study Results}

Average means and variances for the ten cultural dimensions were calculated by arithmetically averaging corresponding questions. A multivariate analysis of variance (MANOVA) was conducted to assess whether cultural characteristics were different among the four countries and four products. MANOVA results revealed that they were. The results of MANOVA are summarized in Table 6. The cultural dimensions were found to be different in terms of different products as well as different countries. The difference in terms of country $(F=$ $\left.78.061, p<.01, \eta^{2}=0.175\right)$ is almost twofold of the product $(F$ $=42.416, p<.01, \eta^{2}=0.103$ ).

Table 6. Results of MANOVA Analysis Comparing to Country and Product Effects

\begin{tabular}{|c|c|c|c|c|}
\hline Independent Variable & $\boldsymbol{d} \boldsymbol{f}$ & $\boldsymbol{F}$ & $\boldsymbol{p}$ & $\boldsymbol{\eta}^{\mathbf{2}}$ \\
\hline Country & 30 & 78.061 & .000 & 0.175 \\
\hline Product & 30 & 42.416 & .000 & 0.103 \\
\hline
\end{tabular}

Also, an analysis of variance (ANOVA) was conducted to determine which cultural characteristics were different among the four countries. ANOVA results revealed that all the ten dimensions were different among four countries and among four products. Table 7 shows the results of the ANOVA test. The product category was found to have a bigger impacts on two cultural dimensions (individualism/collectivism and time perception), whereas the country category was found to have bigger influence on the rest of the cultural dimensions. We conducted post-hoc comparisons using Scheffe statistics. It was found that the four products as well as the four countries caused differentiations in all the ten cultural dimensions. Especially, cellular phone and MP3P showed similar patterns whereas refrigerator and LCD TV showed rather distinctive patterns of cultural characteristics.

\section{Table 7. Result of ANOVA Analysis Comparing to} Country and Product Effects

\begin{tabular}{|c|c|c|c|c|c|c|}
\hline \multirow{2}{*}{ Dependent Variable } & \multicolumn{3}{|c|}{ Country } & \multicolumn{3}{c|}{ Product } \\
\cline { 2 - 7 } & $\boldsymbol{S S}$ & $\boldsymbol{F}$ & $\boldsymbol{\eta}^{\mathbf{2}}$ & $\boldsymbol{S S}$ & $\boldsymbol{F}$ & $\boldsymbol{\eta}^{\mathbf{2}}$ \\
\hline Uncertainty Avoidance & 497.90 & $101.27^{* * *}$ & .076 & 161.58 & $32.86^{* * *}$ & .026 \\
\hline Individualism & 109.65 & $26.50^{* * *}$ & .021 & 711.41 & $171.94^{* * *}$ & .123 \\
\hline Masculinity & 304.17 & $40.51^{* * *}$ & .032 & 211.70 & $28.19^{* * *}$ & .022 \\
\hline Contextuality & 990.89 & $222.13^{* * *}$ & .153 & 17.90 & $4.01^{* * *}$ & .003 \\
\hline Time Perception & 92.88 & $19.62^{* * *}$ & .016 & 97.55 & $20.61^{* * *}$ & .017 \\
\hline Time Orientation & 430.52 & $96.45^{* * *}$ & .073 & 100.17 & $22.44^{* * *}$ & .018 \\
\hline Power Distance & 953.88 & $123.85^{* * *}$ & .092 & 111.46 & $14.47^{* * *}$ & .012 \\
\hline Ascription vs. Achievement & 218.83 & $44.29^{* * *}$ & .035 & 52.79 & $10.68^{* * *}$ & .009 \\
\hline Affective vs. Neutral & 843.89 & $169.68^{* * *}$ & .121 & 302.32 & $60.79^{* * *}$ & .047 \\
\hline Controllability & 322.08 & $73.05^{* * *}$ & .056 & 83.88 & $19.02^{* * *}$ & .015 \\
\hline
\end{tabular}

Since the ANOVA results indicate that all of ten cultural dimensions were substantially different across the four different countries and four different products, a detailed analysis was conducted for each of ten cultural dimensions in terms of cultural difference among different products and countries.

\subsubsection{Uncertainty Avoidance}

The country effects and product effects on the uncertainty avoidance dimensions are shown in Figure 1.

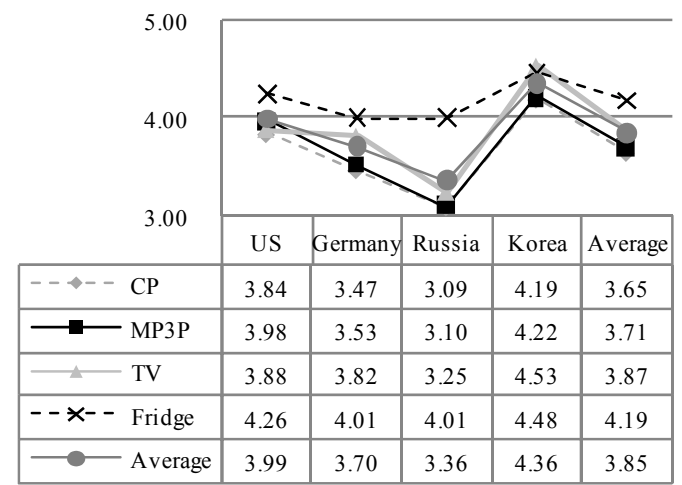

Figure 1. Results on the Uncertainty Avoidance Dimension

As shown in Figure 1, Korean respondents exhibited the highest level of uncertainty avoidance (4.36), whereas Russian people exhibited the lowest level (3.36). In terms of products, uncertainty avoidance towards the refrigerators was the highest (4.19), whereas cellular phones showed the lowest (3.65). This may be because refrigerator users expected a relatively higher level of consistency since broken refrigerators may result in tremendous inconvenience in everyday life especially in Russia. 


\subsubsection{Individualism vs. Collectivism}

The country effects and product effects on the individualism/collectivism dimension are shown in Figure 2. As shown in Figure 2, MP3 players and cellular phones show high degree of individualism in all four countries consistently. On the other hand, LCD-TVs and refrigerators show relatively low individualism even though there are some fluctuations among countries. This may be because MP3 players and cellular phones are devices for individual use, whereas LCD-TVs and refrigerators are mostly shared with family members. These differences appear largest in Russia especially; LCD-TVs and refrigerators marked very low in the degree of individualism, marking 3.62 and 3.45, whereas cellular phones and MP3 players marked 5.37 and 5.33 .

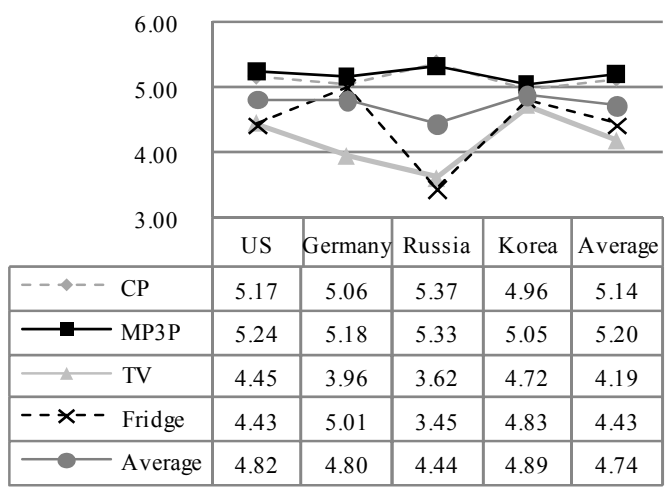

Figure 2. Results on the Individualism vs. Collectivism Dimension

\subsubsection{Masculinity vs. Femininity}

The country effects and product effects on the masculinity / femininity dimensions are shown in Figure 3. As shown in Figure 3, masculinity is highest with LCD-TVs (4.58), whereas the score is lowest with refrigerators (3.93). This may be because male members of the family usually made decisions regarding the purchase and the maintenance of LCD-TVs. In terms of country, Koreans showed the highest level of masculinity (4.65), whereas the other three countries showed almost the same levels.

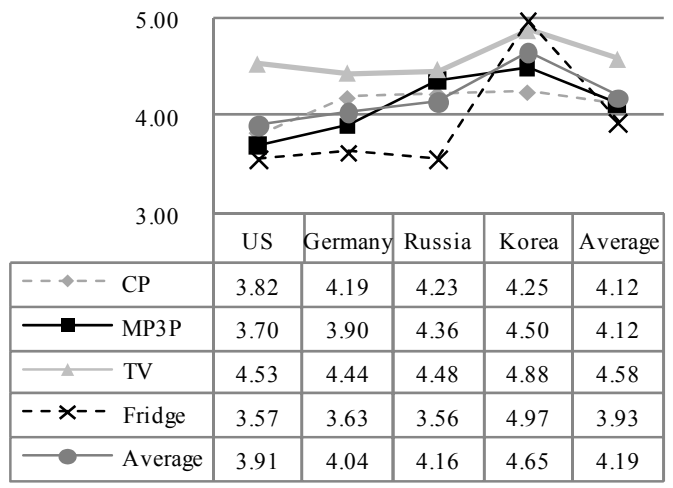

Figure 3. Results on the Masculinity vs. Femininity Dimension

\subsubsection{Contextuality}

The country effects and product effects on the contextuality dimension are shown in Figure 4. As shown in Figure 4, Russian people show the lowest level of contextuality (5.95), whereas American people show the highest level of contextuality (4.58) (reverse coding). All the products marked low in contextuality for Russian users, marking 5.84 (Cellular phone), 5.94 (MP3 player), 5.76 (LCD-TV), and 6.27 (Refrigerator). Few substantial differences are noticed across different products.

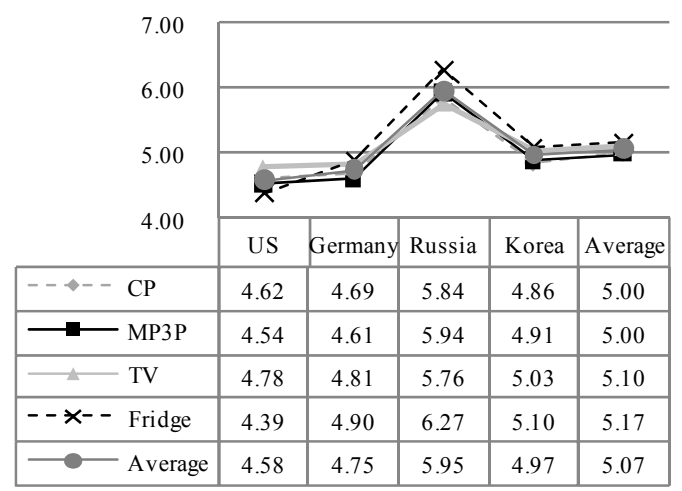

Figure 4. Results on the Contextuality Dimension

\subsubsection{Time perception}

The country effects and product effects on the time perception dimension are shown in Figure 5. As shown in Figure 5, MP3 player (5.13) and LCD-TV (5.12) users exhibited higher polychronic characteristics compared to cellular phone (4.76) and refrigerator users (4.86). The reason may be because people can listen to music via MP3 players or watch LCD TVs while performing other tasks. On the other hand, people need to focus on cellular phones while using it, which leads to a monochronic tendency. In terms of the country effect, Russian people showed the highest level of polychronic culture (5.25).

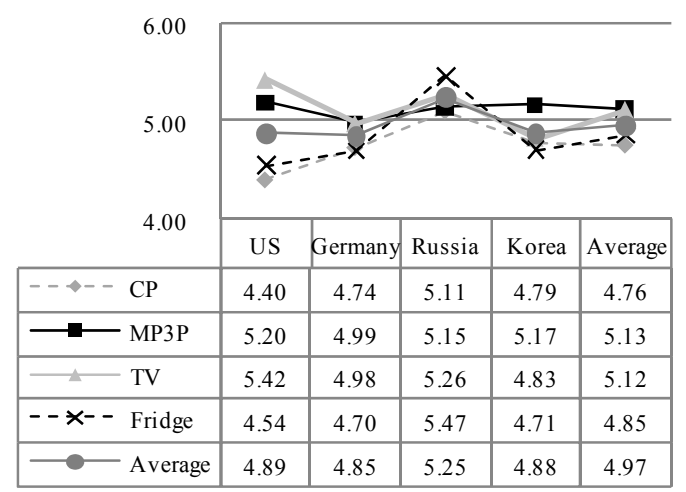

Figure 5. Results on the Time Perception Dimension

\subsubsection{Time Orientation}

The country effects and product effects on the time orientation dimension are shown in Figure 6.

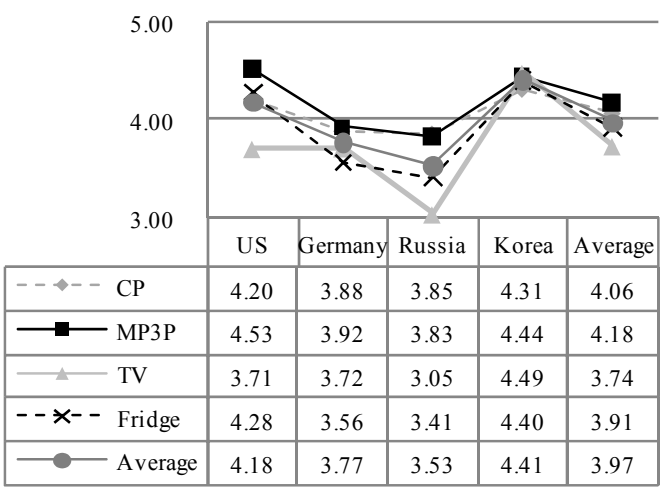

Figure 6. Results on the Time Orientation Dimension 
As shown in Figure 6, LCD-TV (3.74) and refrigerator (3.91) users exhibited relatively higher level of long-term orientation, whereas MP3 player (4.18) and cellular phone (4.06) users inclined more to short-term orientation. This may be because LCD-TVs and refrigerators are relatively more expensive and are durable goods which have longer period of retention time. In terms of country, Russian users (3.54) exhibited the higher level of long-term orientation, whereas Korean users exhibited more on the short-term orientation (4.41).

\subsubsection{Power distance}

The country effects and product effects on the time orientation dimension are shown in Figure 7. As shown in Figure 7, power distance is rather low in most countries and with most products. LCD-TV users exhibited relatively higher level of power distance (3.26). This may be linked with the highest score of masculinity to LCD-TVs as shown in Figure 3. LCD-TV users more readily accept that there is an inequality of power in the decision making process regarding LCD-TVs. Similarly, Korean users exhibited the highest level of power distance (3.63), which can also be related to Korean users having the highest score for masculinity.

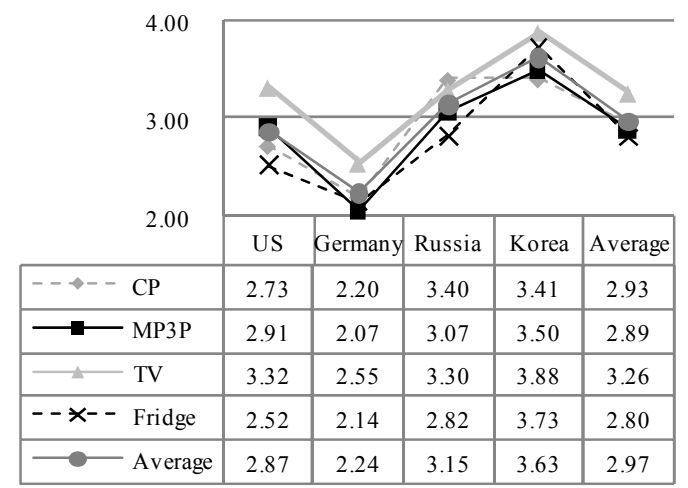

Figure 7. Results on the Power Distance Dimension

\subsubsection{Ascription vs. Achievement}

The country effects and product effects on the ascription/achievement dimension are shown in Figure 8.

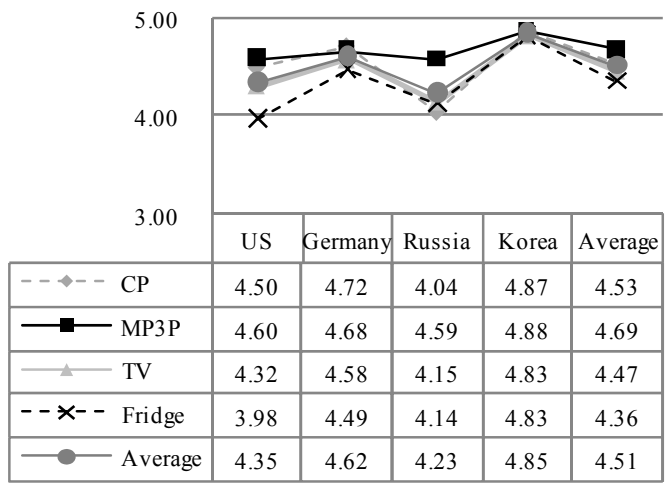

Figure 8. Results on the Ascription vs. Achievement Dimension

As shown in Figure 8, MP3 players have the highest score in achievement (4.46). This indicates that MP3 player users consider product performance and specification more importantly than brand images. This trend may account for the many competing brands in the MP3 player market because they can survive if they perform better in certain product features. In terms of the country effect, Korean users take achievement into consideration relatively more than ascription.

\subsubsection{Affective vs. Neutral}

The country effects and product effects on the affective/neutral dimension are shown in Figure 9. As shown in Figure 9, refrigerator users exhibited the lowest level of affective characteristics (3.16), whereas MP3 player and LCD-TV users exhibited relatively higher level of affective characteristics (3.86, 3.57). This may be because MP3 players and LCD-TVs are mostly used for affective and hedonic purposes, whereas refrigerators are mostly used for utilitarian purpose. In terms of country effect, Korean people exhibited the highest level of affective propensities (4.41).

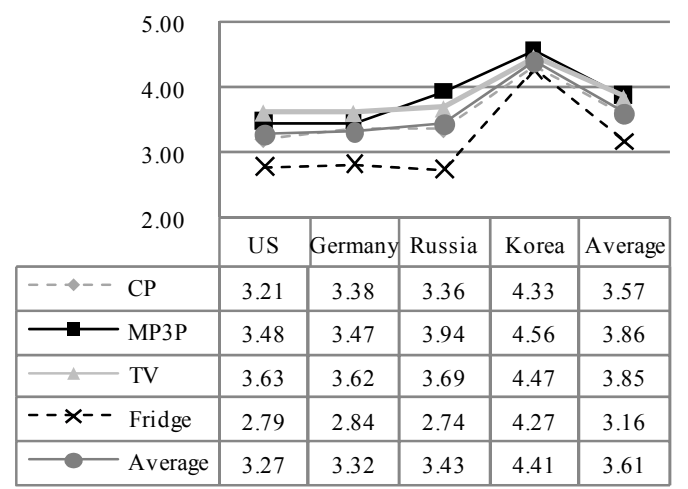

Figure 9. Results on the Affective vs. Neutral Dimension

\subsubsection{Controllability}

The country and products effects on the controllability dimension are shown in Figure 10. As shown in Figure 10, MP3 player and cellular phone users exhibited relatively higher level of controllability $(5.27,5.21)$, whereas refrigerator users exhibited the lowest level of controllability (4.89). This may be because people want to have more control over their personal electronic products compared to shared devices such as refrigerators. In terms of country effects, Russian users showed the highest level of controllability (5.58); whereas American users showed the lowest level of controllability (4.76). This may be because American users regard convenience more importantly than controllability.

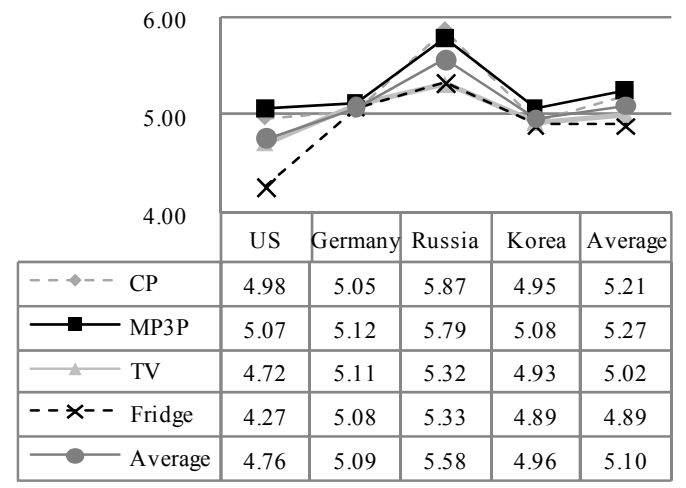

Figure 10. Results on the Controllability Dimension

\section{CONCLUSION AND DISCUSSION}

There are several limitations with this study. First, there is a doubt on whether the four products selected for the study are able to represent the entire range of consumer electronic products. There are other important consumer electronic products that we did not cover such as laptops and washing machines. It will be interesting especially to include familiar but non-technological products such as air conditioners in a 
future study. Moreover, we have not confirmed whether this study can be extended from four countries to the rest of the countries in the world which we have not studied on. This is because we conducted convenient sampling in which the countries were selected from the groups categorized based on the prior research regarding culture in the organizational setting. This may bias our study results because our study is about individual users' cultural traits, whereas the country categorization was done with organizational culture. Third, time and budget allowed the authors to conduct only a few weeks of data collection in each country. Therefore, the number of sessions with expert reviews and contextual inquiries were rather limited. Finally, the last limitation was the self-selection of an online survey. That is, there can be some doubts on whether the respondents who participated in the survey can represent the majority of the country people.

Despite these limitations, there are several theoretical contributions which can be provided by this study. First of all, this study identified ten cultural dimensions that were closely related to the user experience. Moreover, survey questionnaire to measure the cultural dimensions was developed and used to gauge the characteristics of each cultural dimension for four products in four countries. Through this measurement, the study showed that the ten cultural dimensions could represent the cultural characteristics of different countries and products. Moreover, some dimensions were found to be influenced more sensitively by the difference of countries (e.g., contextuality), whereas others were found to be influenced more by the difference of devices (e.g., individualism). The cultural differences among different products, as well as appliance users, have never been measured or identified in prior studies.

On the practical side, this study provides basic guidelines for corporations to adjust their products according to the influence of cultural dimensions on the user experience. For example, Russian users exhibited low contextuality, especially for the refrigerator. This implies that the manuals and on-screen instructions of the refrigerator for the Russian users should be written as specific and detailed as possible. On the other hand, high individualism was consistently observed with MP3 player users, especially in the U.S. and Russia. This implies that MP3 players should be designed to provide various user options in order to suit the individual needs and wants. The basic set of cultural design guidelines should include not only the national differences but also the product differences.

In conclusion, the study identified ten cultural dimensions that were closely related to the user experience of the consumer electronic products. The ten cultural dimensions were found to be affected substantially according to the countries where users resided and the devices which they were using. This study has provided knowledge about cross-country and cross-product cultural characteristics that will enhance our understanding of the intricate interaction between the culture and the user experience- a small but important step toward the development of culture-centered systems.

\section{ACKNOWLEDGEMENTS}

Samsung Electronics generously supported this research. We would like to appreciate Mr. Youngjun Kim and Mr. Kookhyun Chung for their supports. Daniel Kim has been a part of this project while he was working as a summer intern at HCI Lab. Finally, we would like to send our appreciation towards the Principal of Daeil Foreign Language High School for Daniel's participation in the cultural-dimension project.

\section{REFERENCES}

[1] Baumgartner, V. J. and Marcus, A. A Practical Set of Culture Dimensions for Global User-Interface Development. In Proceedings of the 6th Asia-Pacific Conference on Computer-Human Interaction (Hamilton, New Zealand, 2004).

[2] Choi, B., Lee, I., Kim, J., and Jeon,Y. A Qualitative CrossNational Study of Cultural Influences on Mobile Data Service Design. In Proceedings of the 2005 ACM SIGCHI Conference on Human Factors in Computing Systems (Portland, OR, 2005).

[3] Condon, J.C. \& Yousef, F.S. An Introduction to Intercultural Communication. Bobbs-Merrill, Indianapolis, IN, 1981.

[4] Evers, V. Human-Computer Interfaces: Designing for Culture. Unpublished M.S. Dissertation, University of Amsterdam, Netherlands, 1997.

[5] Gallivan, M. and Srite, M. Information Technology and Culture: Identifying Fragmentary and Holistic Perspective of Culture. Information and Organization, 15, 4 (2005), 295-338.

[6] Garfield, M.T. and Watson, R.T. Differences in national information infrastructures: the reflection of national cultures. Journal of Strategic Information Systems, 6, 4 (1998), 313-337.

[7] Glaser, B.G. and Strauss, A.L. The Discovery of Grounded Theory: Strategies for Qualitative Research. Aldine De Gruyter, New York, NY, 1967.

[8] Gould, E.W., Zakaria, N., and S.A.M. Yusof, S.A.M. Applying Culture to Website Design: A Comparison of Malaysian and US Websites. In Proceedings of the 18th Annual ACM International Conference on Computer Documentation: Technology \& Teamwork (Cambridge, MA, 2000).

[9] Hall, E.T. Beyond Culture. Anchor Doubleday Press, Garden City, NY, 1976.

[10] Hiller, M. The Role of Cultural Context in Multilingual Website Usability. Electronic Commerce Research and Applications, 2, 1, (2003), 2-14.

[11] Hofstede, G. Culture's Consequences: Comparing Values, Behaviors, Institutions and Organizations across Nations. Sage Publications, Thousand Oaks, CA, 2001.

[12] Hofstede, G. and Bond, M.H. The Confucius Connection: from Cultural Roots to Economic Growth. Organizational Dynamics, 16, 4, (1988), 5-24.

[13] Kluckhohn, F.R and Strodtbeck, F.L. Variations in Value Orientations. Greenwood Press, Westport, CT, 1961.

[14] Kroeber, A.L. and Parsons, T. The Concept of Culture and of Social System. American Sociological Review, 23, 5 (1958), 582-583.

[15] Marcus, A. and Gould, E.W. Crosscurrents: Cultural Dimensions and Global Web User-Interface Design. Interactions, 7, 4 (2000), 32-46.

[16] Matsumoto, D., Weissman, M.D., Preston, K., Brown, B.R., and Kupperbusch, C. Context-Specific Measurement of Individualism-Collectivism on the Individual Level: The Individualism-Collectivism Interpersonal Assessment Inventory. Journal of Cross-Cultural Psychology, 28 (1997), 743-767. 
[17] Miles, M.B. and Huberman, M. Qualitative Data Analysis: An Expanded Sourcebook. Sage Publications, Thousand Oaks, CA, 1994.

[18] Nakata, C. and Sivakumar, K. National Culture and New Product Development: An Integrative Review. Journal of Marketing, 60, 1 (1996), 61-72.

[19] Overby, J.W., Gardial, S.F., and Woodruff, R.B. French Versus American Consumers' Attachment of Value to a Product in a Common Consumption Context: A CrossNational Comparison. Journal of the Academy of Marketing Science, 32, 4 (2004), 437-460.

[20] Oyserman, D., Coon, H.M., and Kemmelmeier, M. Rethinking Individualism and Collectivism: Evaluation of Theoretical Assumptions and Meta Analyses. Psychological Bulletin, 128, 1 (2002), 3-72.

[21] Parsons, T. and Shils, E.A. Toward a General Theory of Action. Harvard University Press, Cambridge, MA, 1951.

[22] Schimmack, U., Oishi, S., and Diener, E. Individualism: A Valid and Important Dimension of Cultural Differences between Nations. Personality and Social Psychology Review, 9, 1 (2005) 17-31.

[23] Schwartz, S.H. Beyond Individualism-Collectivism: New Cultural Dimensions of Values. In Individualism and
Collectivism: Theory, Method, and Applications, C. Kagitcibasi, S. C. Choi, G. Yoon, U. Kim and H. Triandis (Eds.). Sage Publications, Thousand Oaks, CA, 1994, 85119.

[24] Smith, A., Dunckley, L., French, T., Minocha, S., and Chang, Y. A Process Model for Developing Usable Crosscultural Websites. Interacting with Computers, 16, 1 (2004) 63-91.

[25] Straub, D.W., Loch, W., Aristo, R., Karahanna, E., and Strite, M. Toward a Theory-Based Measurement of Culture. Journal of Global Information Management, 10, 1 (2002) 13-23.

[26] Trompenaars, F. Riding the Waves of Culture: Understanding Diversity in Global Business. Economist Books, London, UK, 1993.

[27] Victor, D.A. International Business Communication. Prentice Hall, New York, NY, 1997.

[28] Watson, R.T., Ho, T.H., and Raman, K.S. Culture: A Fourth Dimension of Group Support Systems. Communications of the ACM, 37, 10 (1994), 44-55.

[29] Wright, Q. The Study of International Relations. AppletonCentury-Crofts, New York, NY, 1955. 